\title{
Identification of suitable housing system for dairy cattle in North East Zone of Tamil Nadu, India, with respect to microclimate
}

\author{
T. Sivakumar, P. T. Suraj, A. Yasotha and Jayashree Phukon \\ Department of Livestock Production Management, Madras Veterinary College, Tamil Nadu Veterinary and \\ Animal Sciences University, Chennai, Tamil Nadu, India. \\ Corresponding author: A. Yasotha, e-mail: dryasotha@gmail.com, \\ TS: tsk63@rediffmail.com,PTS: spullolil@yahoo.co.uk,.JP: jayashreevet@gmail.com \\ Received: 17-07-2016, Accepted: 25-11-2016, Published online: 04-01-2017
}

doi: 10.14202/vetworld.2017.1-5 How to cite this article: Sivakumar T, Suraj PT, Yasotha A, Phukon J (2017) Identification of suitable housing system for dairy cattle in North East Zone of Tamil Nadu, India, with respect to microclimate, Veterinary World, 10(1): 1-5.

\begin{abstract}
Aim: To identify the suitable roofing pattern for dairy cattle in North East Zone of Tamil Nadu, India, based on micro climatic conditions.

Materials and Methods: Initially, survey was conducted to identify and categorize the major housing patterns existing in the region for further detailed investigation. In total, 30 farmers/farms consisting of five housing types with six replicates were selected. Temperature and temperature humidity index (THI) were recorded using the maximum-minimum thermometer and digital thermo-hygrometers. The study was conducted for 1 year covering four seasons namely South West monsoon (June-August), North East monsoon (September-November), cold season (December-February), and summer season (AprilMay). The data were statistically analyzed using statistical package SPSS 17.

Results: Animal shelters with cement sheets recorded the highest temperature $\left(26.71 \pm 1.13^{\circ} \mathrm{C}\right)$ and $\mathrm{THI}(77.23 \pm 1.76)$ at $8.00 \mathrm{am}$, whereas the lowest temperature $\left(24.83 \pm 1.17^{\circ} \mathrm{C}\right)$ and THI $(74.54 \pm 1.72)$ were recorded in the thatched shed. There was significant difference $(\mathrm{p}<0.01)$ in temperature and THI at 8.00 am during South West monsoon and North East monsoon seasons between the housing types. During cold and summer seasons, there was no significant difference ( $\mathrm{p} \geq 0.05)$ in the environmental variables among various shelter systems.
\end{abstract}

Conclusion: Thatched housing is found to be the suitable one with respect to the climatic variables, followed by tile roof and metal roof. The cement sheet roofed housing is found to be the most unsuitable one in the region for dairy cattle.

Keywords: dairy cattle, micro-climate, roofing pattern.

\section{Introduction}

Production and health of animals depend mostly on environment in which they live. A conducive environment for any farm livestock is the one that ensures not only optimal productivity but also meets the health and behavioral needs of the animals. The macro and micro environment have strong influence on farm animals with air temperature having the primary effect, and altered by wind, precipitation, humidity and radiation. Ideally, the impact of the thermal environment can be described in terms of effective ambient temperature which combines the various climatic factors. The extended periods of high ambient temperature coupled with high relative humidity compromise the ability of dairy animals to dissipate excess body heat in Indian climatic conditions [1,2].

In India, the upper temperature limit of comfort zone for optimum milk production is $27^{\circ} \mathrm{C}$, about two degrees higher than the same reported in temperate

Copyright: Sivakumar, et al. Open Access. This article is distributed under the terms of the Creative Commons Attribution 4.0 International License (http://creativecommons.org/licenses/ by/4.0/), which permits unrestricted use, distribution, and reproduction in any medium, provided you give appropriate credit to the original author(s) and the source, provide a link to the Creative Commons license, and indicate if changes were made. The Creative Commons Public Domain Dedication waiver (http:// creativecommons.org/publicdomain/zero/1.0/) applies to the data made available in this article, unless otherwise stated. countries [3]. This is perhaps because the crosses of exotic breed with native Indian breeds have adapted to climatic conditions in the country. However, the average annual temperature is higher than this upper limit in several parts of the country, particularly in South Eastern region comprising of the states of Andhra Pradesh and Tamil Nadu. Even though daily maximum temperatures exceeds $40^{\circ} \mathrm{C}$ for a few hours each day, cool nights help to lose the stored heat which allows the dairy cattle to produce at near optimal levels [4]. In a classical work, Johnson et al. and Zewdu et al. [5,6] reported that milk yield and dry matter intake exhibited significant declines when temperature humidity index (THI) reached 77. Animal productivity and efficiency are significantly influenced by environmental factors. Ambient temperatures above the thermal neutral zone are detrimental to lactation, growth, and reproduction in all livestock, but the effects on the dairy cattle are most economically severe [7-9]. Average daily milk yield/cow (kg) was reduced by 0.886 per unit increase of THI [10]. Studies conducted in New Zealand have demonstrated that the body temperature of dairy cows is related to air temperature and solar radiation [11].

The study was conducted to compare the different housing pattern used for dairy cattle and to find out the suitable one based on the climatic variables 
under which the productivity of dairy cattle is optimum in North Eastern zone of Tamil Nadu.

\section{Materials and Methods \\ Ethical approval}

Ethical approval was not necessary for this study as the study was based on the survey and no animals were involved in the study at any stage of the study.

\section{Location and geographical area under study}

The study was conducted in Vellore and Villupuram districts of the North Eastern zone of Tamil Nadu. The North Eastern zone comprising the districts of Vellore and Villupuram are situated between $12^{\circ} 55^{\prime}$ and $11^{\circ} 57^{\circ}$ of North latitude and $79^{\circ}$ $11^{\prime}$ and $79^{\circ} 32^{\prime}$ 'East longitude with an average elevation of $77 \mathrm{~km}$ above mean sea level. The climate in this zone is basically semi-arid. The annual rainfall of the zone excluding hills varies from 800 to $1400 \mathrm{~mm}$. The average maximum temperature ranges from 28.2 to $38.9^{\circ} \mathrm{C}$ and the minimum from 19.5 to $24.8^{\circ} \mathrm{C}$. The study areas were selected based on the availability of highest cattle population, breedable cattle, and total milk production in these districts. Moreover, no other study of similar nature had been reported from these areas. The first phase of the research involved the data collection on the existing dairy cattle housing patterns in the study area. Initially, survey was conducted among 139 farmers with a structured questionnaire developed in consultation with the extension personnel and subject matter specialists. From the survey, the major housing patterns existing in the region were identified and categorized for further detailed investigation. Farmers with at least five cows were selected with the major types of housing pattern identified for conducting further field investigations.

\section{Type of housing and parameters recorded}

In total, 30 farmers/farms (five housing types with six replicates) were selected from this agro-climatic zone based on the survey to identify the suitable housing system for dairy cattle. The five housing types were selected based on the type of roofing materials used. Those roofing materials were thatched, tile, metal, cement concrete, and open method of rearing. The maximum-minimum thermometer and digital thermo-hygrometers were installed in the dairy cattle sheds of various shelter types for measurement of the climatic variables. The climatic parameters such as maximum temperature $\left({ }^{\circ} \mathrm{C}\right)$, minimum temperature $\left({ }^{\circ} \mathrm{C}\right)$, temperature at $8.00 \mathrm{am}\left({ }^{\circ} \mathrm{C}\right)$, temperature at $2.00 \mathrm{pm}\left({ }^{\circ} \mathrm{C}\right)$, THI at $8.00 \mathrm{am}$, and THI at $2.00 \mathrm{pm}$ were recorded.

\section{Duration of study}

The duration of study was for 1 year and it was divided into four seasons as per [12] as South West monsoon (June-August), North East monsoon (September-November), Cold season (DecemberFebruary), and Summer season (April-May). Data were collected separately from each farm for all the seasons.

\section{Statistical analysis}

The collected data were statistically analyzed by one-way analysis of variances for finding out the differences between the groups using statistical package SPSS 17. The significance was tested using Duncan's multiple range test [13].

\section{Results and Discussion}

Season-wise climatic variables in various housing types in North Eastern zone are presented in Table-1. There was significant difference $(p<0.01)$ during South West monsoon season between the housing types in temperature and THI at $8.00 \mathrm{am}$. Animal shelters with cement sheets recorded the highest temperature $\left(26.71 \pm 1.13^{\circ} \mathrm{C}\right)$ and THI $(77.23 \pm 1.76)$ at $8.00 \mathrm{am}$, whereas the lowest temperature $\left(24.83 \pm 1.17^{\circ} \mathrm{C}\right)$ and $\mathrm{THI}(74.54 \pm 1.72)$ were recorded in the thatched shed.

There was significant difference $(p<0.01)$ in temperature and THI at 8.00 am during South West monsoon and North East monsoon seasons between the housing types. However, during cold and summer seasons, there was no significant difference $(p<0.05)$ in the above parameters. The THI was found to be below the critical mean of $72[14,15]$ during morning 8.00 am in cold season in all the housing systems. During all other periods, it was above the recommended mean value indicating that the environmental stress in animals starts at morning hours of the day.

The minimum temperature recorded during all the four seasons in the zone was within the upper temperature limit of comfort zone for optimum milk production recommended by Dutt et al. [3], Fuquay [16], Mote [17]. However, the temperature at $2.00 \mathrm{pm}$ was above this level in all the housing systems indicating the need for additional heat amelioration measures.

During North East monsoon season also, there was significant difference $(p<0.01)$ between the housing types in temperature and THI at 8.00 am. Animal shelters with cement sheets recorded the highest temperature $\left(26.09 \pm 1.32^{\circ} \mathrm{C}\right)$ and THI $(77.42 \pm 2.00)$ at $8.00 \mathrm{am}$, whereas the lowest temperature $\left(24.29 \pm 1.32^{\circ} \mathrm{C}\right)$ recorded in the thatched shed and lowest THI (74.60 \pm 1.98$)$ recorded in the open.

In the North East monsoon season, the thatched housing system recorded lowest temperature at $8.00 \mathrm{am}$ and $2.00 \mathrm{pm}$, and lowest THI at $8.00 \mathrm{am}$ during South West monsoon, lowest $\mathrm{T}_{\max }$, temperatures at $8.00 \mathrm{am}$ and $2.00 \mathrm{pm}$ during North East monsoon, lowest $\mathrm{T}_{\max }$, temperatures at 8.00 am and $2.00 \mathrm{pm}$ and lowest THI at 8.00 am during cold season, lowest $\mathrm{T}_{\max }$ and temperature at $8.00 \mathrm{am}$. Hence, the thatched housing is found to be suitable one with respect to the climatic variables. Similarly, Bharambe et al. [18] concluded that thatched roof with paddy straw shed effectively ameliorates environmental temperature, humidity and THI during summer season in the Konkan region. Kamal et al. [19], Shekhawat and Chaudhary [20] reported that both thatched, mud 


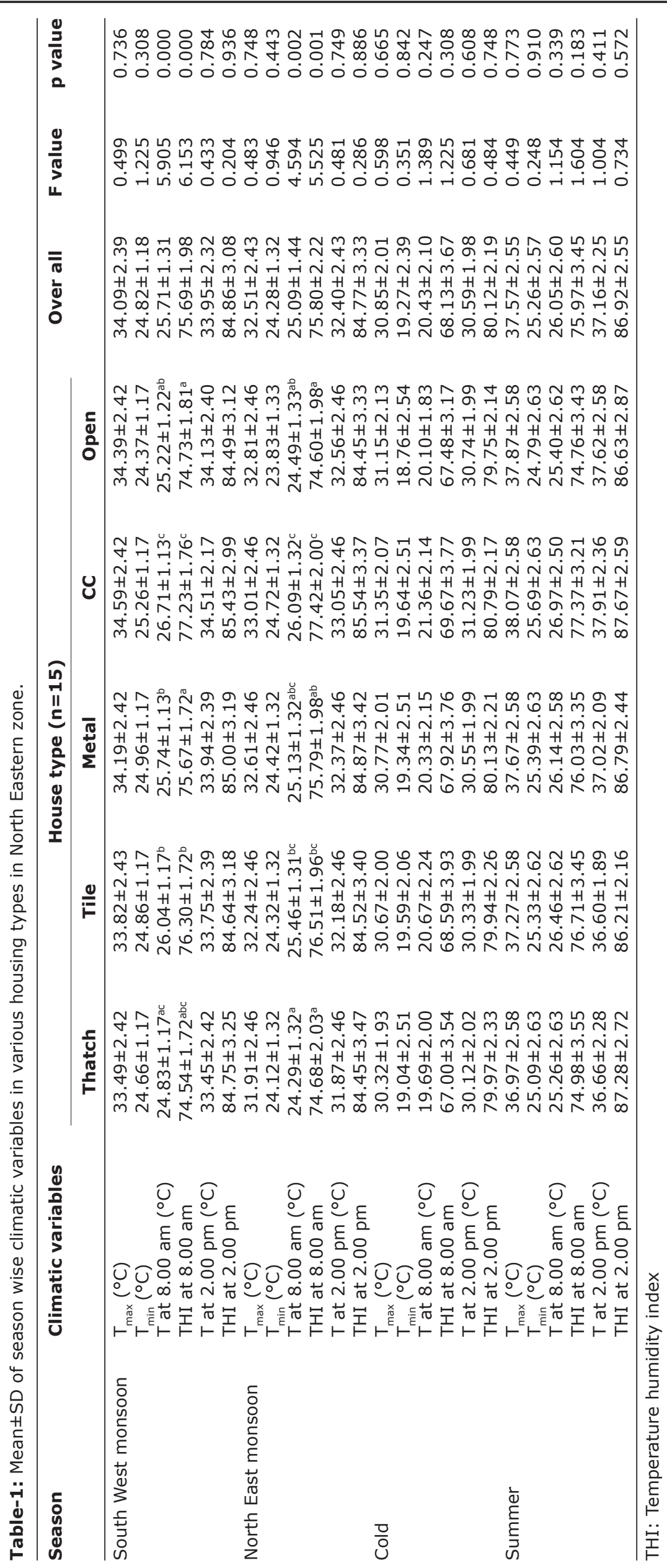


plaster roof, and agro-net shade material were found to be the suitable roofing material for relieving the summer stress in a better way.

The tile roofed housings have shown the second lowest $\mathrm{T}_{\max }$ during all the seasons of the year. This system has shown the least value for THI at $2.00 \mathrm{pm}$ during summer season. Hence, tile roofed housing is also found to be suitable for the region with respect to the microclimate.

During cold and summer seasons, there was no significant difference $(p \geq 0.05)$ in the environmental variables under various shelter systems under study in the North Eastern zone.

The metal roofed shelters were found to show the third position in $\mathrm{T}_{\max }$ during all the four seasons. The THI at $2.00 \mathrm{pm}$ was also on the higher side on the second position.

The cement sheet roofed housing has recorded the highest $\mathrm{T}_{\max }, \mathrm{T}_{\min }$ temperatures at 8.00 am and $2.00 \mathrm{pm}$, THI at 8.00 am and $2.00 \mathrm{pm}$ in all the seasons. Hence, it is found to be the most unsuitable one in this region.

The open housed system has reported the lowest $T_{\min }$ during all the seasons due to increased heat dissipation during night; however at $2.00 \mathrm{pm}$ it has recorded the second highest temperature after the cement sheet roofed housing. Hence, it cannot be recommended as a suitable one without the combination of shade during day time.

It is clear from the study that the morning and evening THI values exceeded critical value of 72 and ranged between $74.54 \pm 1.72$ and $87.67 \pm 2.59$ in all the seasons except cold season. The study also reveals that the dairy cattle in all the housing pattern were in mild stress during monsoon season also. Similar results were also reported by Kamal et al. [1] in cross bred calves. The present finding is also supported by Das [10], Khongdee [21] who found that the difference between maximum and minimum THI during the rainy season was lower indicating that the dairy cows were exposed to heat stress conditions more consistently during the rainy season.

In this study, the lowest minimum temperature $(18.76 \pm 2.54)$ was observed in open type during cold season whereas highest maximum temperature $(38.07 \pm 2.58)$ was recorded in cement concrete roof during summer. There was no significant difference between morning and evening temperature among different roofing types. Whereas, Jat et al. [22], Kamal et al. [23] recorded significantly $(\mathrm{p}<0.01)$ lower maximum temperature in shed with thatched and mud plaster roof than loose house with asbestos sheet and barn house. However, they observed the nonsignificant difference between morning and evening temperature with various roof structures similar to this study.

\section{Conclusion}

The need arises to identify the region based suitable housing pattern for dairy cattle to diminish the challenges imposed by impending climate change. In this regard, the study was conducted to identify the suitable region wise housing system for dairy cattle. The result based on climatic variables in various housing system showed that the minimum temperature recorded during all the four seasons in the zone was within the upper temperature limit of comfort zone for optimum milk production. However, the temperature at $2.00 \mathrm{pm}$ was above this level in all the housing systems indicating the need for additional heat amelioration measures. The result indicated that thatched roof, followed by tile and metal roof housing system are found to be suitable for the North East Zone of Tamil Nadu, India, with respect to the microclimate.

\section{Authors' Contributions}

TS has planned the research work for execution. PTS conducted the study in different housing systems. PTS and JP analyzed the data and performed statistical analysis. AY drafted and revised the manuscript under the guidance of TSK. All authors read and approved the final manuscript.

\section{Acknowledgments}

The authors acknowledge the Indian Council of Agricultural Research, New Delhi, for financial assistance (ICAR approval sanction no. Lr.No. F.122/2008-IA-I dated 9.3.2009) to conduct this research work. All the authors express their sincere thanks to the Vice Chancellor, TANUVAS for providing all necessary facilities to execute the research work.

\section{Competing Interests}

The authors declare that they have no competing interests.

\section{References}

1. Kamal, R., Dutt, T., Patel, B.H.M., Singh, G., Chandran, P.C., Dey, A. and Barari, S.K. (2016) Effect of shade materials on rectal temperature, respiration rate and body surface temperature of crossbred calves during rainy season. Indian J. Anim. Sci., 86: 75-81.

2. Das, R., Sailo, L., Verma, N., Bharti, P., Saikia, J., Imtiwati. and Kumar, R. (2016) Impact of heat stress on health and performance of dairy animals: A review. Vet. World, 9(3): 260-268.

3. Dutt, T., Taneja, V.K. and Singh, A. (1992) Comfort zone for maximal milk production in crossbred cattle. Indian J. Dairy Sci., 45: 119-122.

4. Bouraoui, R., Lahmar, B.M., Majdoub, A., Djemali, M. and Belyea, R. (2002) The relationship of temperature-humidity index with milk production of dairy cows in a Mediterranean climate. Anim. Res., 51: 479-491.

5. Johnson, H.D., Ragsdale, A.C., Berry, I.L. and Shanklin, M.D. (1963) Temperature-humidity effects including influence of acclimation in feed and water consumption of Holstein cattle. Mo. Agric. Exp. Sta. Res. Bulletin No. 846

6. Zewdu, W., Thombre, B.M. and Binwad, D.V. (2014) Effect of macroclimatic factors on milk production and reproductive efficiency of Holstein Friesian and Deoni crossbred cows. J. Cell Anim. Biol., 8(4): 51-60.

7. St-Pierre, N.R., Cobanov, B. and Schnitkey, G. (2003) Economic losses from heat stress by US livestock industries. J. Dairy Sci., 86: 52-77. 
8. Dash, S., Chakravarty, A.K., Singh, A., Upadhyay, A., Singh, M. and Yousuf, S. (2016) Effect of heat stress on reproductive performances of dairy cattle and buffaloes: A review. Vet. World, 9(3): 235-244.

9. Seerapu, S.R., Kancharana, A.R., Chappidi, V.S. and Bandi, E.R. (2015) Effect of microclimate alteration on milk production and composition in Murrah buffaloes. Vet. World, 8(12): 1444-1452.

10. Das, S.K. (2012) Effect of THI on milk production and physiological responses of crossbred cows during different months under the Agro climatic condition of Bihar. Indian J. Anim. Sci., 65: 246-249.

11. Kendall, P.E., Verkerk, G.A., Webster, J.R. and Tucker, C.B (2007) Sprinklers and shade cool cows and reduce insect-avoidance behavior in pasture based dairy systems. J. Dairy Sci., 90: 3671-3680.

12. Shanmugasundaram, S., Kothandaraman, P., Thiagarajan, M., Swaminathan, K.R. and Michael, R.D. (1973) Effect of microclimate on growth. Cherion, 2: 103-109.

13. Duncan, D.E. (1955) Multiple range and multiple F Test. Biometrics, 11: 1-12.

14. Igono, M.O., Jotvedt, G. and Sanford-Crane, H.T. (1992) Environmental profile and critical temperature effects on milk production of Holstein cows in desert climate. Int. J. Biometeorol., 36: 77-87.

15. Kohli, S., Atheya, U.K. and Thapliyal, A. (2014) Assessment of optimum thermal humidity index for crossbred dairy cows in Dehradun district, Uttarakhand, India. Vet. World, 7(11): 916-921.

16. Fuquay, J.W. (1981) Heat stress as it affects animal production. J. Anim. Sci., 52: 164-169.

17. Mote, S.S., Chauhan, D.S. and Ghosh, N. (2016) Effect of environment factors on milk production and lactation length under different seasons in crossbred cattle. Indian J. Anim. Res., 50(2): 175-180.

18. Bharambe, V.Y., Patil, S.M. and Burte, R.G. (2013) Performance of lactating crossbred cows under different housing systems during summer in Konkan agro-ecological conditions. J. Anim. Res., 3: 197-201.

19. Kamal, R., Dutt, T., Patel, B.H.M., Dey, A., Chandran, P.C., Barari, S.K., Chakrabarti, A. and Bhusan, B. (2014) Effect of shade materials on microclimate of crossbred calves during summer. Vet. World, 7: 776-783.

20. Shekhawat, L.S. and Chaudhary, J.L. (2012) Effect of roof modifications in loose house on intake and utilization of nutrients and milk yield in lactating utilization of nutrients and milk yield in lactating crossbred cows during winter season. Indian J. Dairy Sci., 65(6): 501-507.

21. Khongdee, S. (2008) The effects of high temperature and housing modification on the productive and reproductive performance of dairy cows. Thesis Submitted to Graduate School, Kasetsart University.

22. Jat, R.P., Gupta, L.R. and Yadav, B.L. (2005) Effect of roof modification in loose house on intake and utilization of nutrients in buffalo calves during rainy season. Indian $J$. Anim. Sci., 58: 54-57.

23. Kamal, R., Dutt, T., Patel, B.H., Dey, A., Chandran, P.C., Barari, S.K., Chakrabarti, A. and Bhusan, B. (2014) Effect of shade materials on microclimate of crossbred calves during summer. Vet. World, 7(10): 776-783. 